\title{
Lugworm (Abarenicola affinis) in seagrass and unvegetated habitats
}

\author{
Stefan Goerlitz $\cdot$ Katrin Berkenbusch • \\ P. Keith Probert
}

Received: 12 March 2014/Revised: 30 November 2014/ Accepted: 22 December 2014/Published online: 10 January 2015 (c) Springer-Verlag Berlin Heidelberg and AWI 2015

\begin{abstract}
In Otago, southern New Zealand, the lugworm Abarenicola affinis resides in neighbouring tidal inlets with and without seagrass (Zostera muelleri). A comparison of abundance, body size and biomass of $A$. affinis between seagrass habitat (Papanui Inlet) and unvegetated habitat (Hoopers Inlet) showed little seasonal variation of these parameters in each habitat and relatively similar abundances between both habitats. In contrast, lugworm biomass was considerably lower in the seagrass habitat due to the lack of large individuals compared with unvegetated habitat. In the seagrass habitat, there was a significant negative influence of $Z$. muelleri below-ground biomass on abundance and biomass of $A$. affinis, indicating that seagrass affected lugworm burrowing and/or feeding processes. In contrast to the unvegetated habitat, where lugworms spread relatively evenly across the intertidal area, lugworms were mostly restricted to the upper intertidal zone in the seagrass habitat. The findings suggest that the extensive seagrass bed in the mid and low intertidal zones of Papanui Inlet limited lugworm distribution in an otherwise suitable habitat. Whereas small lugworms colonised seagrass areas, the largest individuals occurred only in unvegetated sediment and seemed to be more hampered
\end{abstract}

Communicated by H.-D. Franke.

S. Goerlitz $(\bowtie) \cdot$ K. Berkenbusch · P. K. Probert

Portobello Marine Laboratory, University of Otago,

PO Box 8, Portobello, Dunedin 9014, New Zealand

e-mail: madseason@freenet.de

K. Berkenbusch

e-mail: katrin.berkenbusch@otago.ac.nz

P. K. Probert

e-mail: keith.probert@otago.ac.nz by the presence of seagrass than smaller individuals. The findings highlight negative feedback between antagonistic ecosystem engineers, with the potential of seagrass physical structures (autogenic engineering) to impact negatively on lugworm activity (allogenic engineering).

Keywords Abarenicola affinis - Zostera muelleri . Lugworm habitat comparison - Tidal inlets - Species interactions $\cdot$ Ecosystem engineers $\cdot$ Negative feedback

\section{Introduction}

In coastal sediments, habitat modifying organisms that alter sediment properties and dynamics have a strong influence on the distribution and abundance of other benthic biota (e.g. Reise 2002; Bostroem et al. 2006; Berkenbusch and Rowden 2007; Eriksson et al. 2010). These organisms represent examples within the concept of ecosystem engineering, which is used to describe species that directly or indirectly modify habitat resource flow by causing state changes in the biotic and abiotic environment (Jones et al. 1994). Two types of ecosystem engineers can be distinguished: autogenic engineers modify habitats via their own physical structure, whereas allogenic engineers modify habitats via their activity (Jones et al. 1994). Many recent studies have focussed on the role of benthic ecosystem engineering in intertidal softsediments, which are particularly amenable to habitat modifications (e.g. Berkenbusch and Rowden 2003; Bos et al. 2007; Volkenborn et al. 2007; Ekloef et al. 2011). In these habitats, autogenic and allogenic ecosystem engineers generate complex networks of species interactions, mediated by the transformed sediment matrix (Reise 2002; Bouma et al. 2009). 
Two notable examples of autogenic and allogenic ecosystem engineers on tidal flats are seagrasses and bioturbating lugworms, respectively (Bouma et al. 2009). Both seagrasses and lugworms modify habitats to their own benefit and have the potential to inhibit the distribution and functioning of each other, when co-existing on tidal flats (van der Heide et al. 2007; van Wesenbeeck et al. 2007; Bouma et al. 2009; Ekloef et al. 2011). Sediment processing by lugworms can lead to burial of seagrass seeds and plants, whereas, in turn, established root systems of seagrasses consolidate the sediment, inhibiting reworking and burrowing activities of lugworms (Brenchley 1982; van Wesenbeeck et al. 2007; Valdemarsen et al. 2010; Ekloef et al. 2011).

In view of their ecological significance, lugworm populations have been widely studied, with most research focussing on Arenicola marina, which occurs on the often extensive and relatively homogeneous tidal flats of the north European Atlantic coast (e.g. Beukema and de Vlas 1979; Pollack 1979; Reise et al. 2001). There, the species covers about $70 \%$ of c. $4,700 \mathrm{~km}^{2}$ tidal flat area with an average density of 20-40 individuals per $\mathrm{m}^{2}$ and is considered a structuring agent of regional landscape-forming processes (Beukema 1976; Riisgard and Banta 1998; Reise et al. 2010). In contrast, less is known about lugworm species in other regions of the world, including populations in small semi-enclosed tidal bays, where lugworms are less dominant and exhibit a more patchy distribution (Hobson 1967; Wilson 1981; Krager and Woodin 1993; Goerlitz et al. 2013). Previous studies have shown that lugworm distribution in tidal bays can be limited to certain locations on the shore, which has been associated with changes in habitat type, e.g. sediment vegetation, or hydrodynamic disturbance (Hobson 1967; Swinbanks and Murray 1981).

In southeastern New Zealand, the lugworm Abarenicola affinis (Ashworth 1903) is common in tidal inlets and estuaries, where it co-occurs with the seagrass Zostera muelleri (Irmisch ex Ascherson 1867) in a number of habitats (Wells 1963; Leduc et al. 2006; Goerlitz et al. 2013). Zostera muelleri is a short-bladed seagrass (5-15 cm blade length), which is common on intertidal flats throughout New Zealand, where it often exhibits a patchy distribution (Turner 2007). Zostera muelleri also has dense below-ground structures that may adversely affect macrofauna, including large bioturbators (van Houte-Howes et al. 2004; Berkenbusch et al. 2007). On the Otago coast, southeastern New Zealand, two adjacent tidal inlets are populated by A. affinis but differ in the occurrence of seagrass, with one inlet containing large areas of fragmented and continuous seagrass habitat, and the other inlet containing no seagrass. This difference in sediment vegetation between the two inlets was used in the present study to examine the distribution, abundance, body size and biomass of $A$. affinis in seagrass and unvegetated habitats. The study assesses whether the presence of seagrass has an effect on the measured lugworm parameters in these habitats.

\section{Materials and methods}

\section{Lugworm sampling}

The study was carried out in two neighbouring tidal inlets in southeastern New Zealand, Papanui and Hoopers inlets (Fig. 1). Both inlets are of similar size $\left(\right.$ c. $\left.4 \mathrm{~km}^{2}\right)$ and have semidiurnal tides, with mean tidal ranges of 1.15 and $0.43 \mathrm{~m}$, respectively (Albrecht and Vennell 2007). Whereas lugworms inhabit both inlets, seagrass only occurs in Papanui Inlet, but not in Hoopers Inlet. In Papanui Inlet, Z. muelleri forms an extensive, continuous meadow in the mid and low intertidal zones, whereas the high intertidal zone is characterised by fragmented seagrass habitat (Mills and Berkenbusch 2009).

Field sampling was carried out in four consecutive seasons, in summer (December) 2007, autumn (March), winter (June) and spring (September) 2008. In each inlet, an intertidal sampling area of $0.4 \mathrm{~km}^{2}$ was selected, representing seagrass (Papanui Inlet) and unvegetated habitat (Hoopers Inlet). Both sampling areas included c. 600-700 $\mathrm{m}$ of intertidal area from the shoreline to the mean low tide water mark. Each sampling area was divided by a grid of 90 sampling points, and the position of points and their distance to the shoreline were established by global positioning system (GPS). In both sampling areas, distance from the shoreline corresponded with low tide exposure time ranging between 2 and $9 \mathrm{~h}$ per semidiurnal tidal cycle (visually assessed over $12 \mathrm{~h}$ ). Based on these observations, distance from the shoreline was used as a proxy for tidal level. In both seagrass and unvegetated habitat, 15 sampling points were randomly chosen each season and sampled by collecting a sediment core $(20 \mathrm{~cm}$ diameter or $314 \mathrm{~cm}^{2}$ area to $40 \mathrm{~cm}$ depth). Each sampling core was extracted using a shovel and divided into $10-\mathrm{cm}$ depth sections, which were individually sieved on 1-mm mesh. For each core and depth section, the collected lugworm were transferred into seawater containers for transportation.

In the laboratory, lugworms were anaesthetised for $3 \mathrm{~h}$ in $7 \%$ magnesium chloride, fixed in $4 \%$ formalin and subsequently preserved in $70 \%$ ethanol. Following preservation, total and thorax lengths of lugworms were measured with calipers $( \pm 0.5 \mathrm{~mm})$. To determine ash-free dry weight (AFDW, $\pm 0.0001 \mathrm{~g}$ ), lugworms were dried 


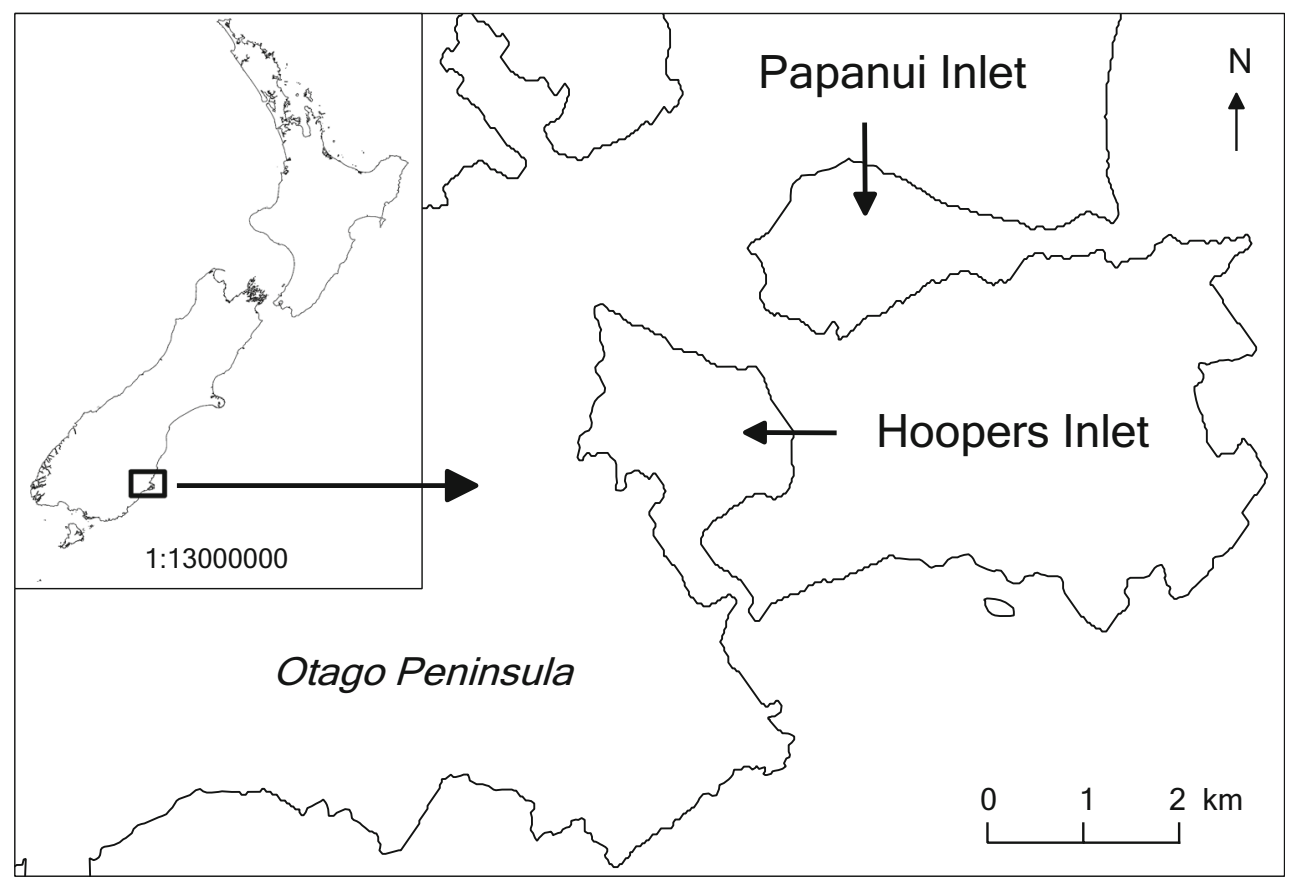

Fig. 1 Location of the intertidal seagrass (Papanui Inlet) and unvegetated (Hoopers Inlet) habitats in southeastern New Zealand

to constant weight $\left(60{ }^{\circ} \mathrm{C}, 48 \mathrm{~h}\right)$ and combusted $\left(500{ }^{\circ} \mathrm{C}, 4 \mathrm{~h}\right)$.

Habitat sampling

At each sampling point, two sediment cores were collected. The first core $(4.7 \mathrm{~cm}$ diameter, $10 \mathrm{~cm}$ depth) was split for sediment granulometry and organic matter content analyses. The second core ( $2.5 \mathrm{~cm}$ diameter, $2 \mathrm{~cm}$ depth) was taken for sediment chlorophyll $a$ analysis. The latter two parameters indicate potential food sources for lugworms in the form of available organic material (including seagrass detritus) and microphytobenthos (Longbottom 1970; Leduc et al. 2006; Widdows et al. 2008). In addition, in the seagrass habitat, seagrass within the lugworm sampling core was cut off at the sediment surface prior to excavation and retained. Seagrass roots, rhizomes and debris in the top 10-cm depth section of the core were subsequently collected during sieving.

In the laboratory, seagrass leaves, roots, rhizomes and debris were rinsed with freshwater, dried $\left(60{ }^{\circ} \mathrm{C}, 48 \mathrm{~h}\right)$ and weighed $( \pm 0.001 \mathrm{~g})$. Sediment samples were wet-sieved to extract the fines fraction $(<63 \mu \mathrm{m})$, dried $\left(60{ }^{\circ} \mathrm{C}, 48 \mathrm{~h}\right)$ and mechanically sieved to determine grain size fractions (63, 125, 250, 500, 1,000 $\mu \mathrm{m}$ ) (McManus 1988). Organic matter content was determined by loss on ignition $\left(500{ }^{\circ} \mathrm{C}\right.$, $4 \mathrm{~h}$ ) (Buchanan and Kain 1971). Sediment chlorophyll $a$ samples were freeze-dried $\left(-50^{\circ} \mathrm{C}, 48 \mathrm{~h}\right)$, homogenised, boiled in $90 \%$ ethanol and analysed using a spectrophotometer (Sartory 1982).
Data analysis

Statistical analyses were conducted with STATISTICA 6.0 (StatSoft 2001) using a significance level of $P<0.05$ for all tests. Examined A. affinis parameters were abundance, thorax length and biomass. Thorax length was selected instead of total length due to the occasional occurrence of incomplete worm tails. One-way ANOVA (Underwood 1997) was applied to test for differences in lugworm parameters across seasons within each habitat and for differences in lugworm parameters between habitats, combining data from all seasons. Data were tested for normality and homogeneity of variances by KolmogorovSmirnov and Cochran tests, respectively (Underwood 1997). Non-normally distributed data were accepted due to ANOVA's robustness against non-normality (Underwood 1997). When necessary, data were square-root or $\log _{10^{-}}$ transformed to achieve homogeneity of variances. Although lugworm abundance data between habitats remained heterogeneous after transformation, ANOVA was considered reliable because test results were non-significant (heterogeneity only compromises the outcome of ANOVA when test results are significant, Underwood 1997). Between both habitats, A. affinis occurred in the size range $17-90 \mathrm{~mm}$ thorax length. Therefore, the size frequency distribution of $A$. affinis within each habitat was evaluated by categorising lugworms into eight arbitrary size classes: 11-20, 21-30, 31-40, 41-50, 51-60, 61-70, 71-80 and 81-90 $\mathrm{mm}$ thorax length. 
In both the seagrass and unvegetated habitat, multiple linear regressions (Quinn and Keough 2002) were used to analyse the relationship between lugworm distribution and habitat variables, and data were combined across all seasons to assess general patterns. Abarenicola affinis abundance and biomass were used as dependent variables. Predictor variables included distance from the shoreline, sediment mean grain size and proportion of fines, and organic matter and chlorophyll $a$ contents. In the seagrass habitat, seagrass above- and below-ground (roots, rhizomes and debris in the top $10 \mathrm{~cm}$ of sediment) biomasses were also included. Prior to analysis, A. affinis abundance and biomass data were $\log _{(x+1)}$-transformed to improve residuals' normality and homogeneity of variances (graphically assessed by probability plots and plots of residuals against predicted values, respectively, Quinn and Keough 2002). Co-correlations were graphically assessed by matrix plots (Quinn and Keough 2002), leading to the omission of sediment mean grain size and seagrass above-ground biomass from the regression analysis in the seagrass habitat due to high correlation $\left(R^{2}>0.5, P<0.001\right)$ with proportion of fines and seagrass below-ground biomass, respectively.

\section{Results}

Lugworm characteristics in seagrass and unvegetated habitats

In both seagrass and unvegetated habitats, A. affinis showed little seasonal variation in mean values of abundance, thorax length and biomass (Table 1). In the seagrass habitat, lugworm abundance was greatest in autumn, compared with summer in the unvegetated habitat. In both types of habitat, lugworm biomass peaked in autumn. Results from

Table 1 Abarenicola affinis abundance and biomass (per $314 \mathrm{~cm}^{2}$ core; mean values $\pm \mathrm{SD}, n=15$ ), and thorax length (mean values $\pm \mathrm{SD}, n=19-31$ ) in summer, autumn, winter and spring

\begin{tabular}{lllllll}
\hline Habitat type & Season & $\begin{array}{l}\text { No. of sampling } \\
\text { cores }\end{array}$ & $\begin{array}{l}\text { No. of } \\
\text { individuals }\end{array}$ & $\begin{array}{l}\text { Mean } \\
\text { abundance } \pm \text { SD }\end{array}$ & $\begin{array}{l}\text { Mean thorax length } \\
(\mathrm{mm}) \pm \text { SD }\end{array}$ & $\begin{array}{l}\text { Mean biomass } \\
(\mathrm{g} \text { AFDW) } \pm \text { SD }\end{array}$ \\
\hline Seagrass (Papanui Inlet) & Summer & 15 & 21 & $1.4 \pm 1.4$ & $31.2 \pm 8.6$ & $0.033 \pm 0.047$ \\
& Autumn & 15 & 29 & $1.9 \pm 2.5$ & $27.4 \pm 5.4$ & $0.047 \pm 0.063$ \\
& Winter & 15 & 20 & $1.3 \pm 1.9$ & $30.0 \pm 6.3$ & $0.033 \pm 0.050$ \\
& Spring & 15 & 19 & $1.3 \pm 1.4$ & $31.0 \pm 7.4$ & $0.045 \pm 0.068$ \\
& Overall & 60 & 89 & $1.5 \pm 1.8$ & $29.6 \pm 6.9$ & $0.040 \pm 0.056$ \\
Unvegetated (Hoopers Inlet) & Summer & 15 & 31 & $2.1 \pm 1.5$ & $43.4 \pm 10.5$ & $0.107 \pm 0.122$ \\
& Autumn & 15 & 22 & $1.5 \pm 1.1$ & $47.6 \pm 13.8$ & $0.163 \pm 0.118$ \\
& Winter & 15 & 21 & $1.4 \pm 1.1$ & $41.9 \pm 11.8$ & $0.101 \pm 0.086$ \\
& Spring & 15 & 22 & $1.5 \pm 1.2$ & $43.6 \pm 14.7$ & $0.100 \pm 0.077$ \\
& Overall & 60 & 96 & $1.6 \pm 1.2$ & $44.1 \pm 12.5$ & $0.118 \pm 0.102$ \\
\hline
\end{tabular}

one-way ANOVA showed that differences in lugworm abundance, thorax length and biomass across seasons were not significant in either habitat (Table 2).

The two habitat types had a similar mean abundance of lugworms, but individuals were noticeably larger in the unvegetated habitat, resulting in greater biomass (Table 1). These differences were consistent across all seasons (and most pronounced in autumn) and were reflected by maximum total lengths and biomasses of lugworms in each habitat (Seagrass habitat: $110 \mathrm{~mm}$; $0.0971 \mathrm{~g}$ AFDW, unvegetated habitat: $175 \mathrm{~mm} ; 0.3982 \mathrm{~g} \mathrm{AFDW})$. Results from one-way ANOVA revealed no significant differences in lugworm abundance between habitats, but significantly greater thorax length and biomass of $A$. affinis in unvegetated habitat compared to seagrass habitat (Table 2).

Size frequency distributions of A. affinis showed that the two types of habitats were populated by lugworms with different ranges of size classes (Fig. 2). In relation to all size classes occupied in each habitat, medium-sized lugworm dominated in both habitats in three of four seasons (Fig. 2). In the seagrass habitat, lugworms occurred only in four smaller size classes with a noticeable peak in the size class 21-30 mm thorax length in autumn. In contrast, in the unvegetated habitat, larger individuals occurred in all seasons, whereas small lugworms ( $<40 \mathrm{~mm}$ thorax length) were generally less abundant compared with the seagrass habitat. In both habitats, the largest individuals were scarce in winter.

In both seagrass and unvegetated habitats, lugworm abundance and body size increased with increasing burrowing depth. Consequently, the differences in $A$. affinis body size between the two habitats resulted also in different burrowing depths (Fig. 3). In the seagrass habitat, lugworms did not occur below $30 \mathrm{~cm}$ depth. In contrast, lugworms in the unvegetated habitat showed their greatest abundance at $30-40 \mathrm{~cm}$ depth. These

(December 2007, March, June, September 2008, respectively) in seagrass and unvegetated habitat 
Table 2 Results of one-way ANOVA (factor season) for Abarenicola affinis abundance and biomass (per $314 \mathrm{~cm}^{2}$ core; $n=15$ ), and thorax length $(n=19-31)$ in seagrass and unvegetated habitat, and results of one-way ANOVA (factor habitat) ( $n=60$ for abundance and biomass; $n=89 / 96$ for thorax length, all seasons) (significant values in bold)

\begin{tabular}{|c|c|c|c|c|c|c|c|c|c|}
\hline \multirow[t]{3}{*}{ Abarenicola affinis parameters } & \multicolumn{6}{|c|}{ Seasonal comparison } & \multicolumn{3}{|c|}{ Habitat comparison } \\
\hline & \multicolumn{3}{|c|}{ Seagrass } & \multicolumn{3}{|c|}{ Unvegetated } & \multirow[b]{2}{*}{$d f$} & \multirow[b]{2}{*}{$F$} & \multirow[b]{2}{*}{$P$} \\
\hline & $d f$ & $F$ & $P$ & $d f$ & $F$ & $P$ & & & \\
\hline Abundance & 3 & 0.41 & 0.750 & 3 & 0.98 & 0.410 & 1 & 0.17 & 0.682 \\
\hline Thorax length (mm) & 3 & 1.63 & 0.190 & 3 & 0.82 & 0.489 & 1 & 101.37 & $<0.001$ \\
\hline Biomass (g AFDW) & 3 & 0.28 & 0.837 & 3 & 1.31 & 0.280 & 1 & 30.44 & $<0.001$ \\
\hline
\end{tabular}
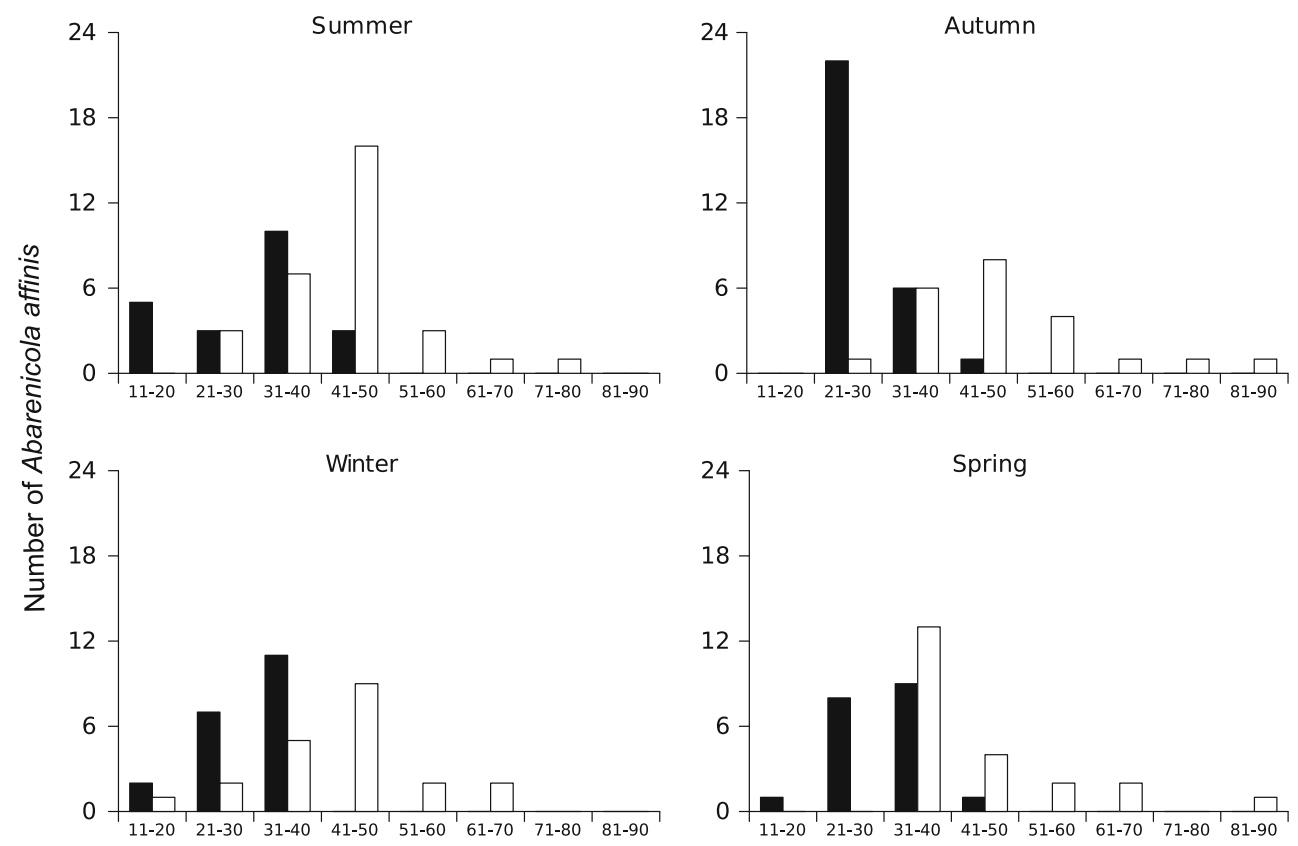

Abarenicola affinis thorax length size class $(\mathrm{mm})$

Fig. 2 Size frequency distributions of Abarenicola affinis in summer, autumn, winter and spring (December 2007, March, June, September 2008 , respectively) in seagrass (filled bars $n=21,29,20,19$, respectively) and unvegetated habitat (open bars $n=31,22,21,22$, respectively)

findings were reflected in the markedly greater mean burrowing depth of lugworms in the unvegetated habitat $[32.7 \pm 7.8(\mathrm{SD}) \mathrm{cm}, n=96]$ compared with the seagrass habitat $(23.6 \pm 6.9 \mathrm{~cm}, n=89)$.

Lugworm distribution in seagrass and unvegetated habitats

Both habitats had relatively similar sediment types with mean sediment grain sizes of $145 \pm 6$ (SD) $\mu \mathrm{m}$ in seagrass habitat and $148 \pm 1 \mu \mathrm{m}$ in unvegetated habitat (both $n=60$, data from all seasons). At the same time, sediment was muddier in the seagrass habitat, as evident in the higher proportion of fines of $4.15 \pm 2.51 \%$ (SD) (maximum $13.2 \%$ ) compared with $2.11 \pm 0.57 \%$ (maximum $3.6 \%$ ) of fines in the unvegetated habitat. Organic matter content was relatively low in both habitat types at
$0.64 \pm 0.13 \%$ (SD) and $0.55 \pm 0.09 \%$ in the seagrass and unvegetated habitat, respectively. The other food variable, microphytobenthos measured as chlorophyll $a$ content, was higher in the unvegetated habitat, with $5.0 \pm 2.3$ (SD) $\mu \mathrm{g}$ chlorophyll $\mathrm{a} / \mathrm{g}$ sediment dry weight compared with $3.7 \pm 1.4 \mu \mathrm{g}$ chlorophyll $\mathrm{a} / \mathrm{g}$ sediment dry weight in the seagrass habitat ( $n=60$, all seasons). In the seagrass habitat, Z. muelleri above-ground and below-ground biomasses were on average $0.143 \pm 0.148$ (SD) g dry weight and $3.833 \pm 2.486 \mathrm{~g}$ dry weight, respectively $(n=60$, all seasons).

In the seagrass habitat, the distribution of A. affinis was significantly influenced by habitat variables, as revealed by multiple linear regression analysis (Table 3 ). The combination of measured habitat variables explained 68 and $71 \%$ of the variation in lugworm abundance and biomass, respectively. Semi-partial correlation coefficients, which 


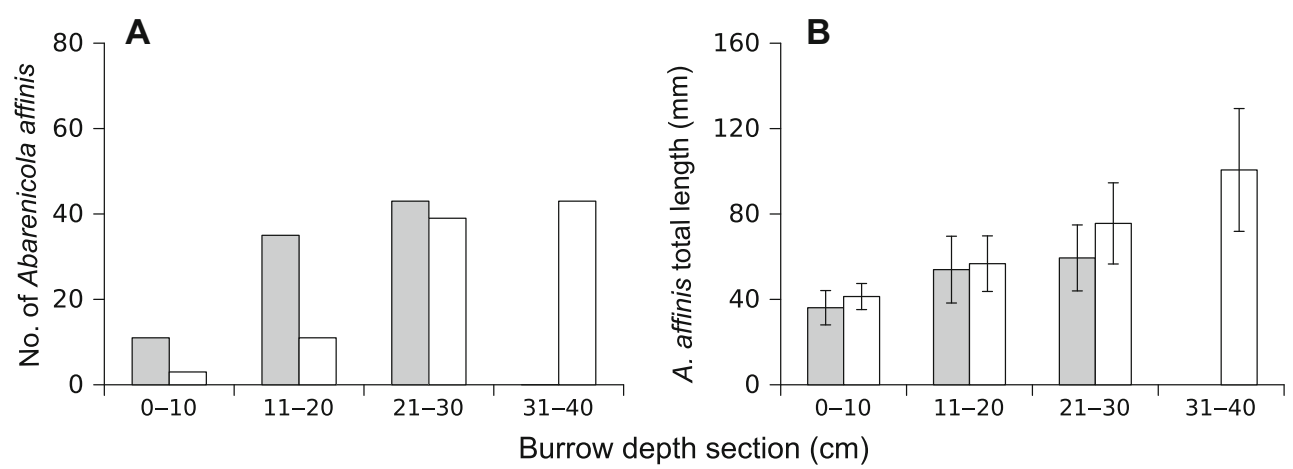

Fig. 3 Total number (a) and total length (b) of Abarenicola affinis (mm, mean values $\pm \mathrm{SD}, n=3-43$ ) per burrow depth section in seagrass (shaded bars) and unvegetated habitat (open bars), sampled between summer 2007 and spring 2008

Table 3 Results of multiple linear regression analyses of Abarenicola affinis abundance and biomass and habitat variables in seagrass and unvegetated habitat (all seasons combined, $n=60$ ) (significant values in bold; $R_{\text {seminart }}^{2}=$ squared semi-partial correlation coefficient,

\begin{tabular}{|c|c|c|c|c|c|c|c|c|}
\hline \multirow[t]{2}{*}{ Habitat type } & \multicolumn{4}{|c|}{ Abarenicola affinis abundance } & \multicolumn{4}{|c|}{ Abarenicola affinis biomass } \\
\hline & $F$ & $R^{2}$ & & $P$ & $F$ & & & $P$ \\
\hline Seagrass & 22.75 & 0.678 & & $<0.001$ & 26.93 & & & $<0.001$ \\
\hline Unvegetated & 0.90 & 0.077 & & 0.490 & 0.94 & & & 0.464 \\
\hline \multicolumn{3}{|c|}{ Seagrass habitat } & $F$ & $R_{\text {semipart }}^{2}$ & $p$ & $F$ & $R_{\text {semipart }}^{2}$ & $p$ \\
\hline \multicolumn{3}{|c|}{ Seagrass below-ground biomass (g dry weight) } & 4.87 & -0.170 & 0.032 & 6.57 & -0.187 & 0.013 \\
\hline \multicolumn{3}{|c|}{ Distance from the shoreline $(\mathrm{m})$} & 39.09 & -0.483 & $<0.001$ & 20.29 & -0.328 & $<0.001$ \\
\hline \multicolumn{3}{|c|}{ Sediment proportion of fines $(\%)$} & 1.62 & 0.010 & 0.209 & 12.42 & 0.257 & $<0.001$ \\
\hline \multicolumn{3}{|c|}{ Organic matter content $(\%)$} & 0.36 & 0.046 & 0.553 & 0.72 & 0.062 & 0.400 \\
\hline \multicolumn{3}{|c|}{ Chlorophyll $a$ content ( $\mu \mathrm{g} / \mathrm{g}$ sediment dry weight) } & 0.29 & -0.041 & 0.596 & 0.17 & -0.030 & 0.684 \\
\hline
\end{tabular}

indicate the relative importance of each variable, were significant for seagrass below-ground biomass and distance from the shoreline; both variables were negatively related to A. affinis abundance and biomass. In addition, the proportion of fines was significantly positively related to A. affinis biomass only, revealing an increase in average lugworm size with increasing proportion of fines in the sediment. By contrast, the measured habitat variables did not explain lugworm distribution in Hoopers Inlet (Table 3).

The distribution patterns of A. affinis in seagrass and unvegetated habitats support the findings of the multiple regression analyses (Fig. 4). In the seagrass habitat, lugworm abundance showed a distinct zonation pattern with respect to distance from the shoreline and the distribution of seagrass. Lugworm abundance was highest in the upper intertidal zone (within $100 \mathrm{~m}$ from the shoreline) and declined with distance from the shoreline. At the same time, seagrass below-ground biomass showed an increase from relatively low levels in the upper intertidal zone to the highest values at about 250-450-m distance from the shoreline. In these lower intertidal areas where seagrass indicating the proportion of variance explained by the inclusion of the predictor variable) biomass was high, lugworm abundance was greatly reduced. A marked decline in lugworm abundance occurred at about 150-m distance from the shoreline, where seagrass showed a considerable increase in below-ground biomass. In contrast, in unvegetated habitat, lugworm abundance was relatively evenly spread throughout the intertidal area, with no clear pattern evident in relation to distance from the shoreline (Fig. 4).

Given the significant influence of seagrass biomass, distance from the shoreline and the proportion of fines on A. affinis distribution in the seagrass habitat, the spatial variation of lugworm size classes in relation to these habitat variables was assessed. The range of each variable was compared across different lugworm size classes, including all samples containing lugworms of the respective size class (Table 4). Whereas the largest A. affinis populated unvegetated areas in the high intertidal zone, where sediment contained the highest proportion of fines, mediumsized lugworms occurred in areas that had no or low seagrass biomass, with a variable proportion of fines and variable distances from the shoreline. The smallest 
individuals (11-20 $\mathrm{mm}$ thorax length) colonised areas of markedly greater seagrass biomass than medium- and large-sized individuals; they also showed a similar distribution across the shore as medium-sized lugworms, but did not occur in the muddiest sediment of this habitat.

\section{Discussion}

Lugworm characteristics in seagrass and unvegetated habitats

In both habitat types, A. affinis showed no marked changes in overall abundance through the year, suggesting temporal stability in the lugworm populations of these habitats. One

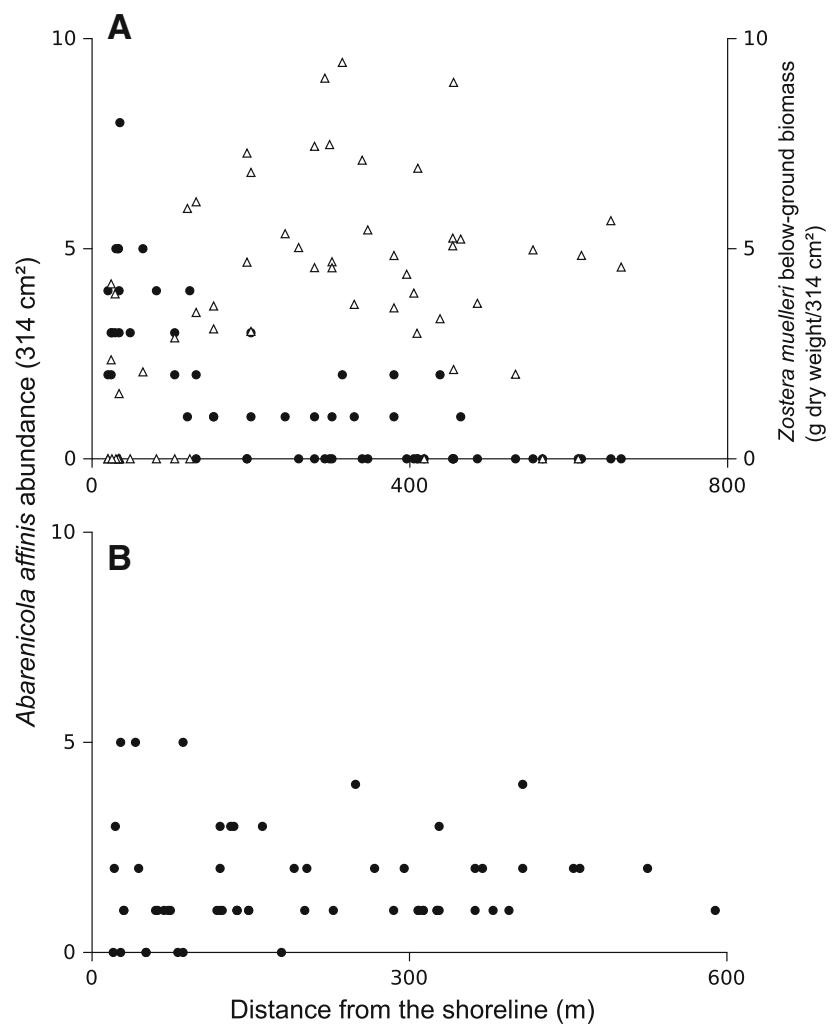

Fig. 4 Abarenicola affinis abundance (filled circle) and Zostera muelleri below-ground biomass (triangle) and distance from the shoreline in seagrass (a) and unvegetated (b) habitat. Data combined from seasonal sampling between summer 2007 and spring 2008 important aspect of this study, however, is that the focus was on adult lugworms, and the sampling design did not include juvenile worms. Furthermore, the generally low population density of $A$. affinis in southern New Zealand (e.g. compared with A. marina in north European tidal bays, Reise et al. 2001; Goerlitz et al. 2013) meant that individual numbers were low. Whereas previous studies have shown that lugworm populations are characterised by temporal stability (Flach and Beukema 1994), seasonal variation may occur, e.g. due to mortality and migration of adult worms into subtidal locations (Reise et al. 2001). In the present study, these kinds of pattern were not evident, but a different sampling design, including the targeting of juvenile worms, is required to elucidate seasonal dynamics in the A. affinis populations.

Although overall abundances were similar in both habitats, lugworms in the seagrass habitat were smaller and had significantly lower biomass compared with lugworms in the unvegetated habitat (also resulting in markedly greater burrowing depth of $A$. affinis in the latter habitat). The size distributions of $A$. affinis indicated a general difference between the two habitats with a greater number of small lugworms and a noticeable lack of large individuals in the seagrass habitat compared with the unvegetated habitat. This difference could originate from different growth and longevity of $A$. affinis between the two habitats, but size-age relationships are unknown for this species. Lugworm growth rates depend on external factors such as food availability (Linton and Taghon 2000). In the present study, sediment organic content was similarly low in both habitat types, whereas microphytobenthos abundance (measured as sediment chlorophyll $a$ concentration) was higher in the unvegetated habitat than in the seagrass habitat. In contrast to other studies that have documented increased organic matter accumulation and microphytobenthos growth in seagrass areas due to attenuation of water flow (Widdows et al. 2008), these effects appear to be less distinct in the seagrass habitat of the present study. As detritus of $Z$. muelleri represented an additional available food source for A. affinis (Leduc et al. 2006), food availability was not considered to be a limiting factor for lugworm growth in the seagrass habitat.

Sampling in the present study did not detect any lugworm $>50 \mathrm{~mm}$ thorax length in Papanui Inlet, and it
Table 4 Abarenicola affinis size classes and habitat variables in seagrass habitat. Data combined from seasonal sampling between summer 2007 and spring 2008

\begin{tabular}{lcclc}
\hline $\begin{array}{l}\text { Thorax length } \\
(\mathrm{mm})\end{array}$ & $\begin{array}{l}\text { No. of } \\
\text { individuals }\end{array}$ & $\begin{array}{l}\text { Seagrass below-ground } \\
\text { biomass (g dry weight) }\end{array}$ & $\begin{array}{l}\text { Distance from } \\
\text { the shoreline }(\mathrm{m})\end{array}$ & $\begin{array}{l}\text { Proportion } \\
\text { of fines }(\%)\end{array}$ \\
\hline $11-20$ & 8 & $2.356-6.815$ & $24-380$ & $2.6-7.2$ \\
$21-30$ & 40 & $0-9.433$ & $20-380$ & $2.2-13.2$ \\
$31-40$ & 36 & $0-9.433$ & $20-464$ & $4.0-13.2$ \\
$41-50$ & 5 & - & $20-81$ & $6.3-13.2$ \\
\hline
\end{tabular}


remains unknown whether individuals of this thorax length are absent from the A. affinis population in this inlet. The lack of large individuals in a lugworm population may be associated with premature mortality or adult migration into subtidal locations (Lackschewitz and Reise 1998; Reise et al. 2001). In the present study, there was no evidence of either pattern. Throughout the sampling, no dead adults were observed on the tidal flat and, there has been no report of $A$. affinis from subtidal regions off the Otago coast to date. The noticeable peak in the number of small individuals (i.e. $21-30 \mathrm{~mm}$ thorax length) in autumn in the seagrass habitat may be the result of post-juvenile recruitment as data derived from gamete observations on A. affinis indicate that individuals $<20 \mathrm{~mm}$ thorax length do not carry gametes in their coelomic fluid, i.e. they are immature (S. Goerlitz unpubl. data). Concentrations of small lugworms in seagrass habitat have been also documented from north European tidal flats (A. marina in Zostera marina beds, Reise 1985). Similarly to its European counterpart, small A. affinis may use the above-ground vegetation of $Z$. muelleri as shelter from predation and environmental stresses.

Lugworm distribution in seagrass and unvegetated habitats

None of the measured habitat variables explained the lugworm distribution in unvegetated habitat, whereas the distribution of $A$. affinis was significantly related to the distribution of $Z$. muelleri, distance from the shoreline and proportion of sediment fines (lugworm biomass only) in the seagrass habitat. In this habitat, below-ground biomass had a significant negative influence on abundance and biomass of A. affinis. At the same time, other habitat variables such as organic matter content and sediment composition were relatively similar between seagrass and unvegetated habitat. These findings indicate that seagrass had a limiting effect on lugworm distribution in an otherwise suitable habitat.

The negative influence of seagrass on lugworm distribution is most likely caused by a reduced burrowing mobility of $A$. affinis within the root structures of $Z$. muelleri, which are difficult to penetrate for large bioturbators (Berkenbusch et al. 2007). The Z. muelleri bed in Papanui Inlet has established an extensive root-rhizome matrix below the sediment surface, and the measured below-ground biomass was comparable to that of other studies documenting impacts of seagrass root mats on macrofaunal distribution in tidal flats (Brenchley 1982; van Houte-Howes et al. 2004). Previous studies have shown that lugworms take considerably longer to re-burrow in seagrass compared with unvegetated sediment (Brenchley 1982). Also, irrigation and feeding activities of lugworms depend on sediment permeability; hence, lugworm maintain permeable conditions to their own benefit when dominating habitats (Volkenborn et al. 2007). In contrast, the cohesive below-ground structures of seagrasses, such as in Z. muelleri, increase sediment compaction (Brenchley 1982; Siebert and Branch 2005; van Wesenbeeck et al. 2007), thus creating less suitable conditions for lugworm feeding activities. For example, headward irrigation by the lugworms, sitting at the lower end of its burrow, creates an upward flow of porewater and loosens the sediment, resulting in a sinking column of particles, on which lugworm feed on (Riisgard and Banta 1998). This process could be severely hampered by seagrass roots, binding the sediment together.

The zonational distribution of $A$. affinis in the seagrass habitat, i.e. the steady decrease in abundance towards the middle of the tidal flat, where seagrass below-ground biomass showed maximum values, suggested that lugworms were more affected by the dense structures within the seagrass bed than at the margin of the bed. This edge effect may arise from a threshold level of below-ground biomass, above which lugworms colonise seagrass areas at lower abundances. A similar effect was reported for deep burrowing polychaetes in estuaries in northern New Zealand, with higher polychaete abundance outside and at the edges of $Z$. muelleri beds, compared with areas inside the beds, where seagrass biomass was highest (van Houte-Howes et al. 2004).

Apart from being spatially limited by the presence of the $Z$. muelleri bed, A. affinis may have concentrated in the high intertidal zone of Papanui Inlet due to less hydrodynamic disturbance in these upper shore areas compared with lower shore areas. An increase in hydrodynamic forces such as tidal currents and wave action in lower shore areas may result in unstable surface sediment, which has negative effects on lugworm burrow maintenance and feeding processes (Hobson 1967; Beukema and de Vlas 1979). A preference of A. affinis for sheltered habitats in near-shore areas has been suggested (Glasby et al. 2009). In the unvegetated habitat in Hoopers Inlet, hydrodynamic disturbance is presumably lower compared with Papanui Inlet due to the narrow entrance channel of the former inlet, resulting in less than half the tidal range and creating a shallow slow-flow environment (Albrecht and Vennell 2007). Therefore, lugworms in lower shore areas in the unvegetated habitat were not limited either by seagrass or by hydrodynamic forces, which may explain their relatively homogeneous distribution across all tidal levels in this habitat.

In the seagrass habitat, the largest $A$. affinis occurred in the finest sediment, which was in the high intertidal zone and coincided with unvegetated areas. The results suggest that an increase in the proportion of fines had an additional 
positive effect on lugworm sizes in this habitat; however, it seems unlikely that this was the case, as lugworms in the unvegetated habitat were considerably larger than the largest individuals in the seagrass habitat, but sediment was relatively coarser compared with the seagrass habitat.

In the seagrass habitat, intertidal areas with greater seagrass biomass contained only the smallest individuals. Small lugworms may be less restricted in their burrowing and feeding activities by seagrass root-rhizome systems compared with larger individuals (Brenchley 1982). In contrast, the limited space of unvegetated sediment in the seagrass habitat seemed to confine larger lugworms in their spatial distribution and may be, in part, responsible for the lack of individuals as large as in the unvegetated habitat. The findings indicate the potential of $Z$. muelleri to influence the spatial distribution of different size classes of $A$. affinis in seagrass-unvegetated habitat mosaic.

In summary, the present study highlights the negative feedback of seagrass on lugworms, whereas other studies have shown mutual negative effects or have emphasised the negative influence of lugworms on the distribution of seagrass in tidal flats (Phillipart 1994; Valdemarsen et al. 2010; Suykerbuyk et al. 2012). Where lugworms and seagrasses co-occur, their opposing ways of modifying the sediment may result in the potential of each ecosystem engineer to prevent the establishment of the other type of engineer (van Wesenbeeck et al. 2007). The present study indicated that such interactions play a role in the variation of lugworm distribution and body size among tidal inlets of southern New Zealand; an established seagrass bed restricted the spatial extent of $A$. affinis, particularly of large individuals, in an otherwise suitable habitat. Given the potential of lugworms to adversely affect seagrass distribution (Phillipart 1994; Suykerbuyk et al. 2012), future research is needed to elucidate factors determining the predominance of either type of organism in joint habitats, as well as factors that may cause shifts in their distributions.

Acknowledgments We thank the University of Otago Department of Marine Science for funding and the Portobello Marine Laboratory for providing all the necessary facilities. We thank René van Baalen for help in the field and Karsten Reise for helpful comments on the initial manuscript. We thank an anonymous referee for valuable comments on the manuscript.

\section{References}

Albrecht N, Vennell R (2007) Tides in two constricted New Zealand lagoons. NZ J Mar Freshw Res 41:103-118

Berkenbusch K, Rowden AA (2003) Ecosystem engineering: moving away from 'just-so' stories. N Z J Ecol 27:67-73

Berkenbusch K, Rowden AA (2007) An examination of the spatial and temporal generality of the influence of ecosystem engineers on the composition of associated assemblages. Aquat Ecol 41:129-147

Berkenbusch K, Rowden AA, Myers TE (2007) Interactions between seagrass and burrowing ghost shrimps and their influence on infaunal assemblages. J Exp Mar Biol Ecol 341:70-84

Beukema JJ (1976) Biomass and species richness of the macrobenthic animals living on the tidal flats of the Dutch Wadden Sea. Neth J Sea Res 10:236-261

Beukema JJ, de Vlas J (1979) Population parameters of the lugworm Arenicola marina, living in tidal flats in the Dutch Wadden Sea. Neth J Sea Res 13:331-353

Bos AR, Bouma TJ, de Kort GLJ, van Katwijk MM (2007) Ecosystem engineering by annual intertidal seagrass beds: sediment accretion and modification. Estuar Coast Shelf Sci 74:344-348

Bostroem C, Jackson EL, Simenstad CA (2006) Seagrass landscapes and their effects on associated fauna: a review. Estuar Coast Shelf Sci 68:383-403

Bouma TJ, Olenin S, Reise K, Ysebaert T (2009) Ecosystem engineering and biodiversity in coastal sediments: posing hypotheses. Helgol Mar Res 63:95-106

Brenchley GA (1982) Mechanisms of spatial competition in marine soft-bottom communities. J Exp Mar Biol Ecol 60:17-33

Buchanan JB, Kain JM (1971) Measurement of the physical and chemical environment. In: Holme NA, McIntyre AD (eds) Methods for the study of the marine benthos. Blackwell, Oxford, pp 30-58

Ekloef JS, van der Heide T, Donadi S, van der Zee EM, O’Hara R, Eriksson BK (2011) Habitat-mediated facilitation and counteracting ecosystem engineering interactively influence ecosystem responses to disturbance. PLoS One 6:e23229

Eriksson BK, van der Heide T, van de Koppel J, Piersma T, van der Veer HW, Olff H (2010) Major changes in the ecology of the Wadden Sea: human impacts, ecosystem engineering and sediment dynamics. Ecosystems 13:752-764

Flach EC, Beukema JJ (1994) Density-governing mechanisms in populations of the lugworm Arenicola marina on tidal flats. Mar Ecol Prog Ser 115:139-149

Glasby CJ, Read GB, Lee KE, Blakemore RJ, Fraser PM, Pinder AM, Erseus C, Moser WE, Burreson EM, Govedich FR, Davies RW, Dawson EW (2009) Phylum Annelida: bristleworms, earthworms, leeches. In: Gordon DP (ed) New Zealand inventory of biodiversity, vol 1., Kingdom Animalia: Radiata, Lophotrochozoa, Deuterostomia Canterbury University Press, Canterbury, pp 312-358

Goerlitz S, Berkenbusch K, Probert PK (2013) Distribution and abundance of Abarenicola affinis (Arenicolidae, Polychaeta) in tidal inlets of Otago, New Zealand. NZ J Mar Freshw Res 47:548-560

Hobson KD (1967) The feeding and ecology of two North Pacific Abarenicola species (Arenicolidae, Polychaeta). Biol Bull 133:315-335

Jones CG, Lawton JH, Shachak M (1994) Organisms as ecosystem engineers. Oikos 69:373-386

Krager CD, Woodin SA (1993) Spatial persistence and sediment disturbance of an arenicolid polychaete. Limnol Oceanogr 38:509-520

Lackschewitz D, Reise K (1998) Macrofauna on flood delta shoals in the Wadden Sea with an underground association between the lugworm Arenicola marina and the amphipod Urothoe poseidonis. Helgol Meeresunters 52:147-158

Leduc D, Probert PK, Frew RD, Hurd CL (2006) Macroinvertebrate diet in intertidal seagrass and sandflat communities: a study using $\mathrm{C}, \mathrm{N}$ and $\mathrm{S}$ stable isotopes. NZ J Mar Freshw Res 40:615-629

Linton DL, Taghon GL (2000) Feeding, growth, and fecundity of Abarenicola pacifica in relation to sediment organic concentration. J Exp Mar Biol Ecol 254:85-107 
Longbottom MR (1970) The distribution of Arenicola marina with particular reference to the effects of particle size and organic matter of the sediments. J Exp Mar Biol Ecol 5:138-157

McManus J (1988) Grain size determination and interpretation. In: Tucker M (ed) Techniques in sedimentology. Blackwell, Oxford, pp 63-85

Mills VS, Berkenbusch K (2009) Seagrass (Zostera muelleri) patch size and spatial location influence infaunal macroinvertebrate assemblages. Estuar Coast Shelf Sci 81:123-129

Phillipart CJM (1994) Interactions between Arenicola marina and Zostera noltii on a tidal flat in the Wadden Sea. Mar Ecol Prog Ser 111:251-257

Pollack H (1979) Population dynamics, productivity and energetics of the lugworm Arenicola marina (Annelida, Polychaeta). Helgol Meeresunters 32:313-358

Quinn GP, Keough MJ (2002) Experimental design and data analysis for biologists. Cambridge University Press, Cambridge

Reise K (1985) Tidal flat ecology. An experimental approach to species interactions. Springer, Berlin

Reise K (2002) Sediment mediated species interactions in coastal waters. J Sea Res 48:127-141

Reise K, Simon M, Herre E (2001) Density-dependent recruitment after winter disturbance on tidal flats by the lugworm Arenicola marina. Helgol Mar Res 55:161-165

Reise K, Baptist M, Burbridge P, Dankers N, Fischer L, Flemming B, Oost AP, Smit C (2010) The Wadden Sea: a universally outstanding tidal wetland. Wadden Sea Ecosystem 29. Common Wadden Sea Secretariat, Wilhelmshaven, pp 7-24

Riisgard HU, Banta GT (1998) Irrigation and deposit feeding by the lugworm Arenicola marina, characteristics and secondary effects on the environment. A review of current knowledge. Vie et Milieu 48:243-257

Sartory D (1982) Spectrophotometric analysis of chlorophyll $a$ in freshwater phytoplankton. Technical report. Hydrological Research Institute, Pretoria

Siebert T, Branch GM (2005) Interactions between Zostera capensis and Callianassa kraussi: influences on community composition of eelgrass beds and sandflats. Afr J Mar Sci 27:357-373

StatSoft (2001) STATISTICA 6.0. StatSoft, Tulsa

Suykerbuyk W, Bouma TJ, van der Heide T, Faust C, Govers LL, Giesen WBJT, de Jong DJ, van Katwijk MM (2012) Suppressing antagonistic bioengineering feedbacks doubles restoration success. Ecol Appl 22:1224-1231

Swinbanks DD, Murray JW (1981) Biosedimentological zonation of Boundary Bay tidal flats, Fraser River Delta, British Columbia. Sedimentology 28:201-237

Turner SJ (2007) Growth and productivity of intertidal Zostera capricorni in New Zealand estuaries. NZ J Mar Freshw Res 41:77-90

Underwood AJ (1997) Experiments in ecology. Cambridge University Press, Cambridge

Valdemarsen T, Wendelboe K, Egelund JT, Kristensen E, Flindt MR (2010) Burial of seeds and seedlings by the lugworm Arenicola marina hampers eelgrass (Zostera marina) recovery. J Exp Mar Biol Ecol 410:45-52

van der Heide T, van Nes EH, Geerling GW, Smolders AJP, Bouma TJ, van Katwijk MM (2007) Positive feedbacks in seagrass ecosystems: implications for success in conservation and restoration. Ecosystems 10:1311-1322

van Houte-Howes KSS, Turner SJ, Pilditch CA (2004) Spatial differences in macroinvertebrate communities in intertidal seagrass habitats and unvegetated sediment in three New Zealand estuaries. Estuaries 27:945-957

van Wesenbeeck BK, van de Koppel J, Herman PMJ, Bakker JP, Bouma TJ (2007) Biomechanical warfare in ecology: negative interactions between species by habitat modification. Oikos 116:742-750

Volkenborn N, Hedtkamp SIC, van Beusekom JEE, Reise K (2007) Effects of bioturbation and bioirrigation by lugworms (Arenicola marina) on physical and chemical sediment properties and implications for intertidal habitat succession. Estuar Coast Shelf Sci 74:331-343

Wells GP (1963) The lugworms of the southern cold temperate zone (Arenicolidae, Polychaeta). Proc Zool Soc Lond 140:121-159

Widdows J, Pope ND, Brinsley MD, Asmus H, Asmus RM (2008) Effects of seagrass beds (Zostera noltii and Z. marina) on nearbed hydrodynamics and sediment resuspension. Mar Ecol Prog Ser 111:251-257

Wilson WH (1981) Sediment-mediated interactions in a densely populated infaunal assemblage: the effects of the polychaete Abarenicola pacifica. J Mar Res 39:735-748 